\author{
Arkadiusz Polecki \\ Generalna Dyrekcja Dróg Krajowych i Autostrad \\ Oddział we Wrocławiu \\ apolecki@gddkia.gov.pl
}

DOI: $10.35117 / A \_E N G \_18 \_11 \_03$

\title{
Pavement structures highways and expressways on the Lower Silesia area. State of the end 2018's.
}

\begin{abstract}
The current increase in road traffic, an increase in the total weight of lorries and the load on individual vehicle axles, have resulted in the need for widespread use of pavements, which allow the transmission of increased loads. The article presents a qualitative and quantitative analysis of the pavement structure used on lower Silesia's highways and expressways and division into individual sections of classes $\mathrm{A}$ and $\mathrm{S}$ in the area of operation of the Wrocław branch of GDDKiA has been demonstrated
\end{abstract}

Keywords: highways, expressway, pavement structure.

\section{Introduction}

Currently, the length of the national road network in Poland is over 19,300 km. At the end of $2018,3471.95 \mathrm{~km}$ of expressways remain in use, including $1638.450 \mathrm{~km}$ of motorways and $1833.500 \mathrm{~km}$ of expressways. The length of the whole network of national roads in Lower Silesia is $1309.433 \mathrm{~km}$ (1774.644 $\mathrm{km}$ in development per one carriageway), of which approximately $435 \mathrm{~km}$ are expressways.

\section{Length of expressways}

The length of highways in Lower Silesia amounts to $435.452 \mathrm{~km}$, which is $12.54 \%$ of all highways in Poland. In the area of operation of the Wrocław branch of GDDKiA, $49 \%$ of the networks are class $\mathrm{A}$ and $\mathrm{S}$.

All highways in Lower Silesia have a structure that allows the load to be transferred 115 $\mathrm{kN} / \mathrm{axis}$. 


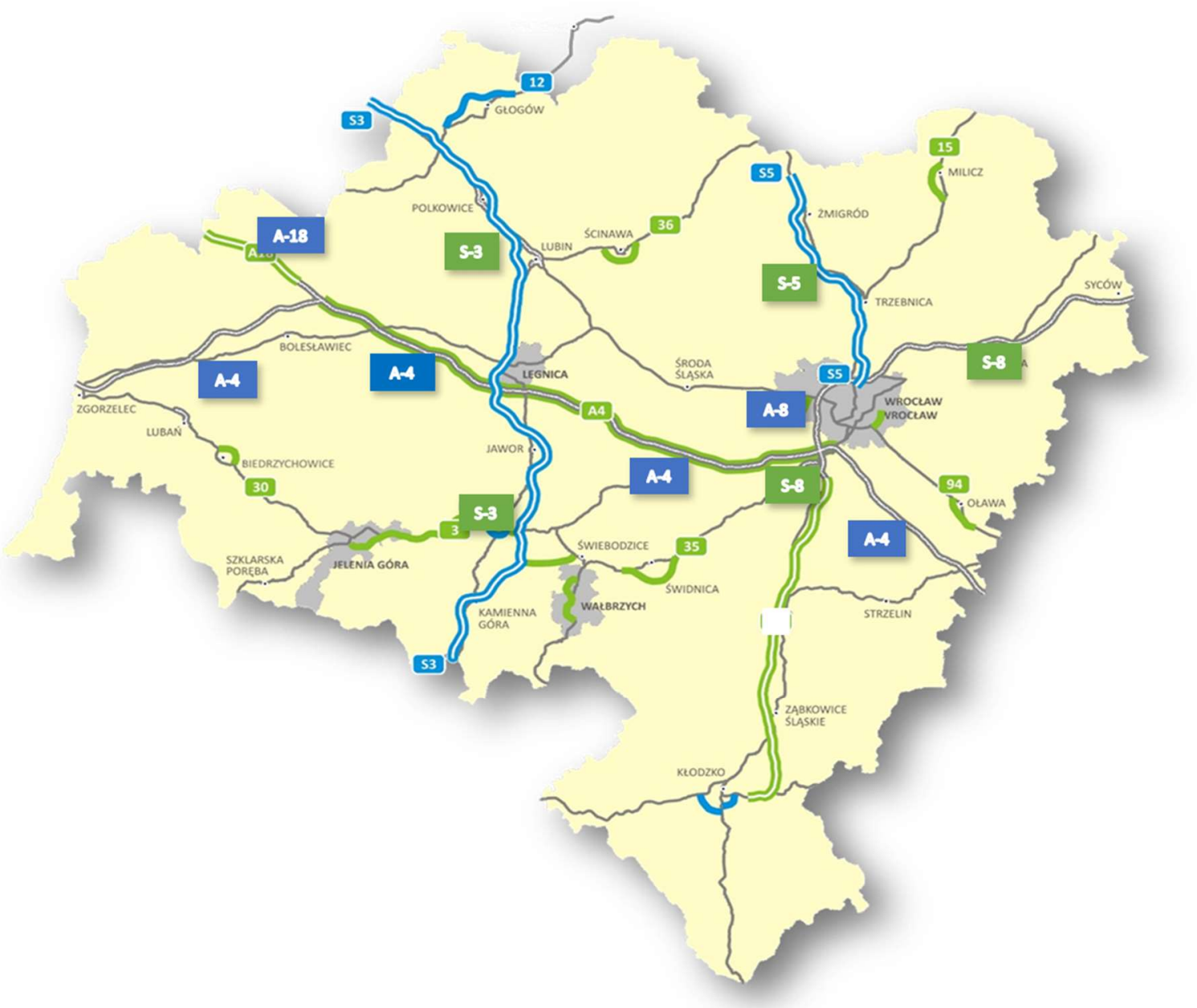

1. A network of national roads and fast traffic in Lower Silesia. (Source: GDDKiA Wrocław Branch.)

\section{The length of highways in Lower Silesia}

The total length of motorways in the area administered by GDDKiA Wrockaw Branch is $222.278 \mathrm{~km}$, which is $13.57 \%$ of all motorways in Poland. In Lower Silesia, there are: A-4 motorway with a length of 193,965 km, connecting the border with Germany in the west with the province border in the east; A-8 motorway with a length of $22.722 \mathrm{~km}$, which is the motorway ring road of Wrocław (AOW); A-18 motorway with a length of $5.591 \mathrm{~km}$ between the Golnice junction ( $\mathrm{dk} 18$ ) and the Krzyżowa interchange (A-4).

\section{The length of expressways in Lower Silesia}

The total length of expressways in Lower Silesia is $213.174 \mathrm{~km}$, which accounts for $11.63 \%$ of all expressways in Poland. In the area administered by GDDKiA Branch in Wrocław, there are: S-3 expressway with a length of $100.328 \mathrm{~km}$, connecting the province's border in the north with Bolków in the south (ultimately with the border with the Czech Republic); S-5 expressway, 53,450 km long, connecting the province's border in the north with the Wrockaw bypass of the Wrocław AOW; S-8 express road, $59.396 \mathrm{~km}$ long, which connects the Wrocław bypass (AOW) with the border of the voivodship (towards Warsaw)).

\section{Surface constructions}

The surface structure (surface) is a set of appropriately selected layers, the purpose of which is to distribute the stresses from the vehicle wheels to the ground surface of the pavement and 
to ensure the safety and comfort of driving vehicles. The surface structure rests on the ground surface or on the layer of the improved substrate.

The rigid pavement structure consists of a topcoat made of cement concrete (dowel or not, anchored or not, reinforced or not), a slip layer, a base structure made of unbound compounds, bituminous concretes, compounds bound by hydraulic binders, an auxiliary foundation (source: Catalog Typical Structures of Rigid Surfaces, pp. 16-19).

The structure of the susceptible surface - the construction of the surface, in which the wear and binding layers are made of asphalt mixtures, and none of the foundation layers are made of materials bound with hydraulic binders. (source: Catalog of Typical Structures of Paving and Semi-rigid Surfaces, p. 15).On motorways used in Lower Silesia, there are both rigid pavement constructions and flexible pavement constructions. The subject pavement constructions were made of cement concrete as well as mineral-asphalt mixtures.

\section{Highways with rigid construction}

Motorways with a rigid pavement structure are A-4 section with a length of about $154 \mathrm{~km}$ (Jędrzychowice - Bielany Wrocławskie) and A-18 with a length of approx. $5.5 \mathrm{~km}$ (Golnice Krzyżowa). The location of sections with a rigid structure is shown in Figure 2 (sections No. $1,2,3,6)$.

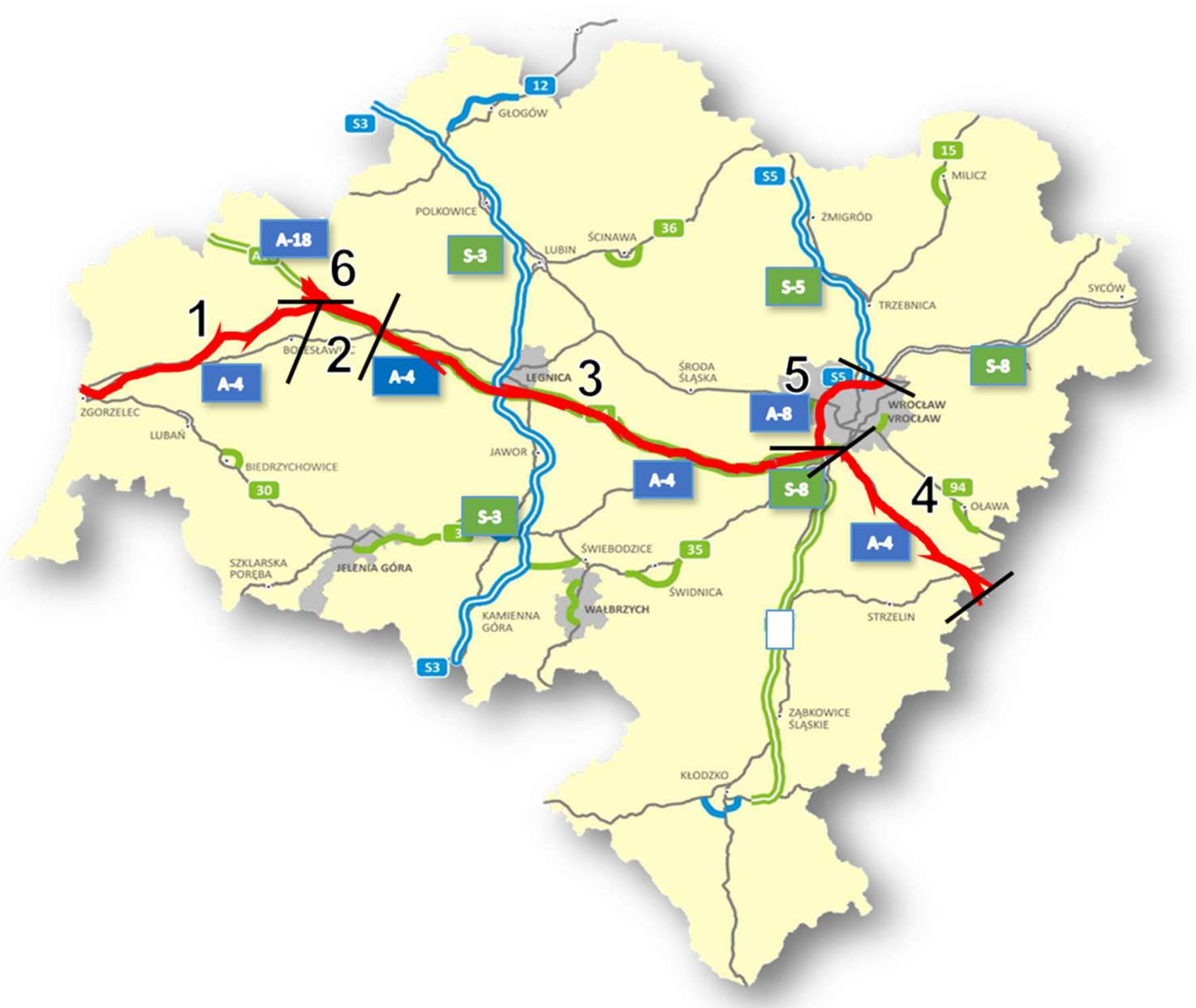

2. Sections of highways in Lower Silesia. (Source: GDDKiA Wrocław Branch.)

Types of rigid constructions are presented in Tables 1 - 3 . 
Tab. 1. Construction of the A-4 motorway, section 1. (Source: GDDKiA Wrocław Branch.)

\begin{tabular}{|c|c|c|}
\hline Thickness & Type of layer & Type of material \\
\hline $27 \mathrm{~cm}$ & driveway & $\begin{array}{c}\text { Cement concrete B-40, compressive strength after } 28 \text { days R2 } 28=40 \\
\mathrm{MPa} \text {, flexural strain at } 5.5 \mathrm{MPa}, 3,3 \mathrm{MPa} \text { stretching at splitting, } 3 \% \\
\text { aeration, water absorption at 5\%. }\end{array}$ \\
\hline$<1 \mathrm{~cm}$ & $\begin{array}{c}\text { dowel and } \\
\text { anchored }\end{array}$ & Nonwovens, $500 \mathrm{~g} / \mathrm{m}^{2}$ \\
\hline $18 \mathrm{~cm}$ & slip & Cement concrete compressive strength $\mathrm{R}_{\mathrm{m}} \geq 6-9 \mathrm{MPa}$ (Lean concrete) \\
\hline $15 \mathrm{~cm}$ & foundation & Crushed-stone aggregate mechanically stabilized $-0 / 31,5$ \\
\hline $20 \mathrm{~cm}$ & frost protection & $\begin{array}{c}\text { Natural Aggregate Mechanically Stabilized - secondary deformation } \\
\text { module (VSS pressure plate) } \mathrm{E}_{2} \geq 120 \mathrm{MPa}\end{array}$ \\
\hline & substrate & Native ground $\mathrm{E}_{2} \geq 60 \mathrm{MPa}$ \\
\hline
\end{tabular}

Tab. 2. The construction of the A-4 and A-18 motorway, sections 2 and 6. (Source: GDDKiA Wrocław Branch.)

\begin{tabular}{|c|c|c|}
\hline Thickness & Type of layer & Type of material \\
\hline $7 \mathrm{~cm}$ & upper driveway & $\begin{array}{r}\text { Cement concrete B-35, concrete mix 0/16, } \mathrm{R}_{28}=35 \mathrm{MPa} \text {, aeration } 4.5 \%, \\
\text { water absorption up to } 5 \% .\end{array}$ \\
\hline $19 \mathrm{~cm}$ & $\begin{array}{c}\text { bottom driveway, } \\
\text { doweled and } \\
\text { anchored }\end{array}$ & $\begin{array}{c}\text { Cement concrete B-35, concrete mix } 0 / 32 \text { (grit from crushed old } \\
\text { concrete slabs), } \mathrm{R}_{28}=35 \mathrm{MPa} \text {, aeration } 4.5 \% \text {, water absorption up to } \\
5 \% .\end{array}$ \\
\hline $15 \mathrm{~cm} /$ & foundation \\
$20 \mathrm{~cm}$ & Groundcement $\mathrm{R}_{7} \geq 4.0 \mathrm{MPa}, \mathrm{R}_{28} \geq 6.0 \mathrm{MPa}$, freezing point 0.7 \\
\hline $15 \mathrm{~cm}$ & frost protection & Unbound ground from the existing G1 and G2 road corps. \\
\hline & substrate & Native ground \\
\hline
\end{tabular}

Tab. 3. The construction of the A-4 motorway, section 3. (Source: GDDKiA Wrocław Branch.)

\begin{tabular}{|c|c|c|}
\hline Thickness & Type of layer & Type of material \\
\hline $27 \mathrm{~cm}$ & $\begin{array}{c}\text { driveway, } \\
\text { doweled and } \\
\text { anchored }\end{array}$ & $\begin{array}{c}\text { Beton cementowy B-40, } \mathrm{R}_{28}=40 \mathrm{MPa} \text {, rozciąganie przy zginaniu 5,5 } \\
\text { MPa, nasiąkliwość do 5\%. }\end{array}$ \\
\hline$<1 \mathrm{~cm}$ & slip & Nonwovens \\
\hline $20 \mathrm{~cm}$ & foundation & Cement concrete $\mathrm{R}_{\mathrm{m}} \geq 6,0-9,0 \mathrm{MPa}$ (Lean concrete) \\
\hline $35 \mathrm{~cm}$ & frost protection & Crushed-stone aggregate mechanically stabilized \\
\hline $15 \mathrm{~cm}$ & $\begin{array}{c}\text { improved } \\
\text { substrate }\end{array}$ & $\begin{array}{c}\text { The ground stabilized with cement } \mathrm{R}_{\mathrm{m}}=1.5-2.5 \mathrm{MPa}-0 / 31,5 ; \mathrm{E}_{2} \geq \\
150 \mathrm{MPa}\end{array}$ \\
\hline & substrate & Native ground \\
\hline
\end{tabular}




\section{Highways with flexible structure}

Motorways with a compliant pavement structure are A-4 section with a length of approx. 40 $\mathrm{km}$ (Bielany Wrocławskie - the border of the province) and A-8 with a length of approx. 22.7 $\mathrm{km}$ (Wrocław Południe - Wrocław Psie Pole). The location of sections with a susceptible structure has been placed on the drawing No. 2 (sections No. 4, 5). The types of susceptible structures are presented in tables $4-5$.

Tab. 4. The construction of the A-4 motorway, section 4. (Source: GDDKiA Wrocław Branch.)

\begin{tabular}{|c|c|c|}
\hline $\begin{array}{c}\text { Thickn } \\
\text { ess }\end{array}$ & Type of layer & Type of material \\
\hline $4 \mathrm{~cm}$ & wearing & Mineral - asphalt mix - SMA 11S (grit mastic) \\
\hline $8 \mathrm{~cm}$ & binding & Mineral-asphalt mix - ACWMS 16 W (asphalt concrete with a high \\
stiffness modulus)
\end{tabular}

Tab. 5. Construction of the A-8 motorway, section 5. (Source: GDDKiA Wrocław Branch.)

\begin{tabular}{|c|c|c|}
\hline Thickness & Type of layer & Type of material \\
\hline $4 \mathrm{~cm}$ & wearing & Mineral - asphalt mix - SMA 11 S \\
\hline $8 \mathrm{~cm}$ & binding & Mineral - asphalt mix - ACWMS $16 \mathrm{~W}$ \\
\hline $18 \mathrm{~cm}$ & foundation & Mineral - asphalt mix - ACWMS $16 \mathrm{P}$ \\
\hline $22 \mathrm{~cm}$ & $\begin{array}{c}\text { unbound } \\
\text { foundation }\end{array}$ & $\begin{array}{c}\text { Crushed-stone aggregate mechanically stabilized }-0 / 31,5 ; \mathrm{E}_{2} \geq 180 \\
\mathrm{MPa}\end{array}$ \\
\hline $25 \mathrm{~cm}$ & frost protection & Unbound mixture, CBR $>40 \%, \mathrm{E}_{2} \geq 150 \mathrm{MPa}$ \\
\hline & substrate & Native ground $\mathrm{E}_{2} \geq 40 \mathrm{MPa}$ \\
\hline
\end{tabular}




\section{Constructions of express road surfaces}

On expressways used in the area administered by GDDKiA Wrocław Branch, there are only vulnerable pavement constructions, all of which have been made of asphalt mixtures. The location of sections of expressways with a susceptible structure has been placed on drawing No. 3.

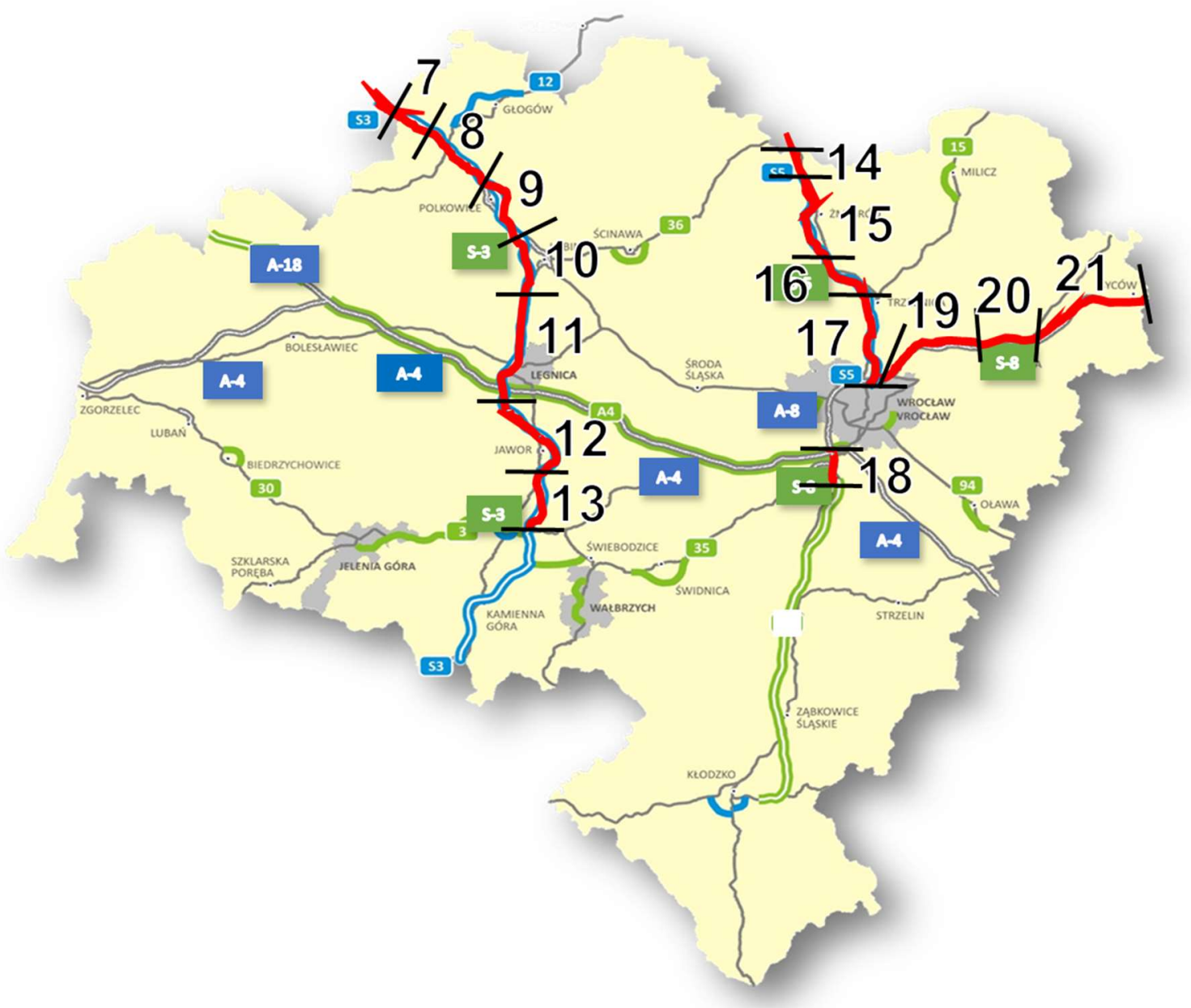

3. Sections of express roads in Lower Silesia. (Source: GDDKiA Wrocław Branch)

\section{Express roads with a pavement structure with classic asphalt concrete}

Sections of expressways whose susceptible pavement structure contains binding layers and foundations are made of asphalt concrete (asphalt mixtures) are presented on drawing 3. These are sections of roads S-3 No. 9 and No. 12 and S-8 No. 20. Types susceptible structures are presented in Tables $6-8$. 
Tab. 6. Construction of the S-3 expressway, section 9. (Source: GDDKiA Wrocław Branch.)

\begin{tabular}{|c|c|c|}
\hline Thickness & Type of layer & Type of material \\
\hline $4 \mathrm{~cm}$ & wearing & Mineral - asphalt mix - SMA 11 S \\
\hline $10 \mathrm{~cm}$ & binding & Mineral-asphalt mix - AC 16 W (asphalt concrete) \\
\hline $16 \mathrm{~cm}$ & foundation & Mineral - asphalt mix - AC 22 P \\
\hline $15 \mathrm{~cm}$ & $\begin{array}{c}\text { unbound } \\
\text { foundation }\end{array}$ & Crushed-stone aggregate mechanically stabilized - 0/31,5; $\mathrm{E}_{2} \geq 180$ \\
MPa
\end{tabular}

Tab. 7. Construction of the S-3 expressway, section 12. (Source: GDDKiA Wrocław Branch.)

\begin{tabular}{|c|c|c|}
\hline Thickness & Type of layer & Type of material \\
\hline $4 \mathrm{~cm}$ & wearing & Mineral - asphalt mix - SMA 11 S \\
\hline $8 \mathrm{~cm}$ & binding & Mineral - asphalt mix - AC 16 W \\
\hline $18 \mathrm{~cm}$ & foundation & Mineral - asphalt mix - AC 22 P \\
\hline $20 \mathrm{~cm}$ & $\begin{array}{c}\text { unbound } \\
\text { foundation }\end{array}$ & Crushed-stone aggregate mechanically stabilized $-0 / 31,5 ; \mathrm{E}_{2} \geq 180$ \\
\hline $30 \mathrm{~cm}$ & $\begin{array}{c}\text { upper layer of } \\
\text { embankment } / \\
\text { excavation }\end{array}$ & Ground G1, or Ground stabilized with cement, $\mathrm{E}_{2} \geq 80 \mathrm{MPa}$ \\
\hline & substrate & Native ground \\
\hline
\end{tabular}

Tab. 8. Construction of the S-8 expressway, section no. 20. (Source: GDDKiA Wrocław Branch.)

\begin{tabular}{|c|c|c|}
\hline Thickness & Type of layer & Type of material \\
\hline $4 \mathrm{~cm}$ & wearing & Mineral - asphalt mix - SMA 0/12,8 S \\
\hline $9 \mathrm{~cm}$ & binding & Mineral - asphalt mix - BA (AC) 0/20 W \\
\hline $18 \mathrm{~cm}$ & foundation & Mineral - asphalt mix - BA (AC) 0/25 P \\
\hline $20 \mathrm{~cm}$ & $\begin{array}{c}\text { unbound } \\
\text { foundation }\end{array}$ & Crushed-stone aggregate mechanically stabilized $-0 / 31,5 ; \mathrm{E}_{2} \geq 180 \mathrm{MPa}$ \\
\hline $12 \mathrm{~cm}$ & $\begin{array}{c}\text { improved } \\
\text { substrate }\end{array}$ & Ground stabilized with cement, $\mathrm{R}_{\mathrm{m}}=2,5 \mathrm{MPa}$ \\
\hline $15 \mathrm{~cm}$ & $\begin{array}{c}\text { improved } \\
\text { substrate }\end{array}$ & Ground stabilized with cement, $\mathrm{R}_{\mathrm{m}}=1,5 \mathrm{MPa}$ \\
\hline
\end{tabular}




\section{Express roads with a pavement structure with asphalt concrete with a high stiffness module}

Sections of expressways, which susceptible pavement structure contains foundation and binding layers made of asphalt concrete with a high stiffness modulus (asphalt mixtures), are presented in Figures 3. These are sections of the S-3 road No. 7, 8, 10, 11, 13; sections of the S-5 road No. 14, 15, 16, 17; sections of the S-8 road No. 18, 19, 21. The types of susceptible structures are presented in Tables $9-16$.

Tab. 9. Construction of the S-3 expressway, sections No. 7 and No. 8. (Source: GDDKiA Wrocław Branch.)

\begin{tabular}{|c|c|c|}
\hline Thickness & Type of layer & Type of material \\
\hline $4 \mathrm{~cm}$ & wearing & Mineral - asphalt mix - SMA 11 S \\
\hline $10 \mathrm{~cm}$ & binding & Mineral - asphalt mix - ACWMS 16 W \\
\hline $13 \mathrm{~cm}$ & foundation & Mineral - asphalt mix - ACWMS 22 P \\
\hline $20 \mathrm{~cm}$ & $\begin{array}{c}\text { unbound } \\
\text { foundation }\end{array}$ & Crushed-stone aggregate mechanically stabilized - 0/31,5; $\mathrm{E}_{2} \geq 180$ \\
\hline $15 \mathrm{~cm}$ & $\begin{array}{c}\text { MPa } \\
\text { frost protection }\end{array}$ & Unbound mix, CBR $>40 \%$ \\
\hline $10 \mathrm{~cm}$ & $\begin{array}{c}\text { technology } \\
\text { upper layer of } \\
\text { embankment } \\
\text { excavation }\end{array}$ & Ground stabilized with cement, $\mathrm{C}_{1,5 / 2,0}$ \\
\hline & \begin{tabular}{c} 
substrate \\
\hline
\end{tabular} & Ground G1 \\
\hline
\end{tabular}

Tab. 10. Construction of the S-3 expressway, section 10. (Source: GDDKiA Wrocław Branch.)

\begin{tabular}{|c|c|c|}
\hline Thickness & Type of layer & Type of material \\
\hline $4 \mathrm{~cm}$ & wearing & Mineral - asphalt mix - SMA 11 S \\
\hline $10 \mathrm{~cm}$ & binding & Mineral - asphalt mix - ACWMS 16 W (lepiszcze 20/30) \\
\hline $12 \mathrm{~cm}$ & foundation & Mineral - asphalt mix - ACWMS 16 P (lepiszcze 20/30) \\
\hline $20 \mathrm{~cm}$ & $\begin{array}{c}\text { unbound } \\
\text { foundation }\end{array}$ & $\begin{array}{c}\text { Crushed-stone aggregate mechanically stabilized }-0 / 31,5 ; \mathrm{E}_{2} \geq 180 \\
\text { MPa }\end{array}$ \\
\hline $15 \mathrm{~cm}$ & frost protection & Mix $\mathrm{C}_{90 / 3}$ unbound CBR $>35 \%, \mathrm{E}_{2} \geq 140 \mathrm{MPa}$ \\
\hline $10 \mathrm{~cm}$ & $\begin{array}{c}\text { technology } \\
\text { Mix } \mathrm{C}_{90 / 3}, \mathrm{CBR}>40 \%\end{array}$ \\
\hline $50 \mathrm{~cm}$ & $\begin{array}{c}\text { upper layer of } \\
\text { embankment } / \\
\text { excavation }\end{array}$ & Grunt G1 or Ground stabilized with cement, $\mathrm{E}_{2} \geq 120 \mathrm{MPa}$ \\
\hline & substrate & Native ground \\
\hline
\end{tabular}


Tab. 11. Construction of the S-3 expressway, section No. 11. (Source: GDDKiA Wrocław Branch.)

\begin{tabular}{|c|c|c|}
\hline Thickness & Type of layer & Type of material \\
\hline $4 \mathrm{~cm}$ & wearing & Mineral - asphalt mix - SMA 11 S \\
\hline $8 \mathrm{~cm}$ & binding & Mineral - asphalt mix - ACWMS 16 W \\
\hline $15 \mathrm{~cm}$ & foundation & Mineral - asphalt mix - ACWMS 22 P (lepiszcze 20/30) \\
\hline $20 \mathrm{~cm}$ & $\begin{array}{c}\text { unbound } \\
\text { foundation }\end{array}$ & Crushed-stone aggregate mechanically stabilized $-0 / 31,5 ; \mathrm{E}_{2} \geq 180$ \\
\hline $15 \mathrm{~cm}$ & $\begin{array}{c}\text { Urost protection } \\
\text { fround mix, CBR }>35 \%, \mathrm{E}_{2} \geq 150 \mathrm{MPa}\end{array}$ \\
\hline & $\begin{array}{c}\text { upper layer of } \\
\text { embankment } / \\
\text { excavation }\end{array}$ & Ground G1, ground stabilized with cement $\mathrm{R}_{\mathrm{m}}=2,5 \mathrm{MPa}, \mathrm{E}_{2} \geq 100 \mathrm{MPa}$ \\
\hline & substrate & Native ground \\
\hline
\end{tabular}

Tab. 12. Construction of the S-3 expressway, section 13. (Source: GDDKiA Wrocław Branch.)

\begin{tabular}{|c|c|c|}
\hline Thickness & Type of layer & Type of material \\
\hline $4 \mathrm{~cm}$ & wearing & Mineral - asphalt mix - SMA $11 \mathrm{~S}$ \\
\hline $11 \mathrm{~cm}$ & binding & Mineral - asphalt mix - ACWMS $16 \mathrm{~W}$ \\
\hline $12 \mathrm{~cm}$ & foundation & Mineral - asphalt mix - ACWMS $16 \mathrm{P}$ \\
\hline $20 \mathrm{~cm}$ & $\begin{array}{l}\text { unbound } \\
\text { foundation }\end{array}$ & $\begin{array}{l}\text { Crushed-stone aggregate mechanically stabilized }-0 / 31,5 ; \mathrm{E}_{2} \geq 180 \\
\qquad \mathrm{MPa}\end{array}$ \\
\hline $10 \mathrm{~cm}$ & strengthening & Mix 0/31,5 (C90/3), unbound; CBR $\geq 60 \%, \mathrm{E}_{2} \geq 140 \mathrm{MPa}$ \\
\hline $25 \mathrm{~cm}$ & $\begin{array}{l}\text { upper layer of } \\
\text { embankment / } \\
\text { excavation }\end{array}$ & Grround G1, or ground stabilized with cement, $\mathrm{E}_{2} \geq 80 \mathrm{MPa}$ \\
\hline & substrate & Native ground \\
\hline
\end{tabular}


Tab. 13. Construction of the S-5 expressway, section No. 14. (Source: GDDKiA Wrocław Branch.)

\begin{tabular}{|c|c|c|}
\hline Thickness & Type of layer & Type of material \\
\hline $4 \mathrm{~cm}$ & Wearing & Mineral - asphalt mix - SMA 11 S \\
\hline $8 \mathrm{~cm}$ & binding & Mineral - asphalt mix - ACWMS 16 W \\
\hline $16 \mathrm{~cm}$ & foundation & Mineral - asphalt mix - ACWMS 16 P \\
\hline $22 \mathrm{~cm}$ & $\begin{array}{c}\text { unbound } \\
\text { foundation }\end{array}$ & Crushed-stone aggregate mechanically stabilized $-0 / 31,5 ; \mathrm{E}_{2} \geq 180$ \\
$\mathrm{MPa}$
\end{tabular}

Tab.14. Construction of the S-5 express road, section 15. (Source: GDDKiA Wrocław Branch.)

\begin{tabular}{|c|c|c|}
\hline Thickness & Type of layer & Type of material \\
\hline $4 \mathrm{~cm}$ & wearing & Mineral - asphalt mix - SMA 11 S \\
\hline $8 \mathrm{~cm}$ & binding & Mineral - asphalt mix - ACWMS 16 W \\
\hline $14 \mathrm{~cm}$ & foundation & Mineral - asphalt mix - ACWMS $16 \mathrm{P}$ \\
\hline $20 \mathrm{~cm}$ & $\begin{array}{c}\text { unbound } \\
\text { foundation }\end{array}$ & $\begin{array}{c}\text { Crushed-stone aggregate mechanically stabilized }-0 / 31,5 ; \mathrm{E}_{2} \geq 180 \\
\mathrm{MPa}\end{array}$ \\
\hline $15 \mathrm{~cm}$ & improved substrate & Ground stabilized with cement, $\mathrm{R}_{\mathrm{m}}=2,5 \mathrm{MPa}\left(\mathrm{C}_{1,5 / 2}\right)$ \\
\hline $35 \mathrm{~cm}$ & $\begin{array}{c}\text { upper layer of } \\
\text { embankment } \\
\text { excavation }\end{array}$ & Ground G1, $\mathrm{E}_{2} \geq 80 \mathrm{MPa}$ \\
\hline & substrate & Native ground \\
\hline
\end{tabular}

Tab. 15. Construction of the S-5 expressway, section 16 and 17. (Source: GDDKiA Wrocław Branch.)

\begin{tabular}{|c|c|c|}
\hline Thickness & Type of layer & Type of material \\
\hline $4 \mathrm{~cm}$ & wearing & Mineral - asphalt mix - SMA 11 S \\
\hline $11 \mathrm{~cm}$ & binding & Mineral - asphalt mix - ACWMS 16 W \\
\hline $11 \mathrm{~cm}$ & foundation & Mineral - asphalt mix - ACWMS $16 \mathrm{P}$ \\
\hline $20 \mathrm{~cm}$ & $\begin{array}{c}\text { unbound } \\
\text { foundation }\end{array}$ & $\begin{array}{c}\text { Crushed-stone aggregate mechanically stabilized }-0 / 31,5 ; \mathrm{E}_{2} \geq 180 \\
\text { MPa }\end{array}$ \\
\hline $30 \mathrm{~cm}$ & frost protection & Unbound mix, CBR $>35 \%, \mathrm{E}_{2} \geq 140 \mathrm{MPa}$ \\
\hline $30 \mathrm{~cm}$ & $\begin{array}{c}\text { upper layer of } \\
\text { embankment } /\end{array}$ & Ground G1, or Ground stabilized with cement, $\mathrm{E}_{2} \geq 60 \mathrm{MPa}$ \\
\hline
\end{tabular}




\begin{tabular}{|l|l|l|}
\hline & excavation & \\
\hline & substrate & Native ground \\
\hline
\end{tabular}

Tab. 16. The construction of the S-8 expressway, sections 18, 19, 21. (Source: GDDKiA Wrocław Branch.)

\begin{tabular}{|c|c|c|}
\hline $\begin{array}{c}\text { Thickn } \\
\text { ess }\end{array}$ & Type of layer & Type of material \\
\hline $4 \mathrm{~cm}$ & wearing & Mineral - asphalt mix - SMA 11 S \\
\hline $8 \mathrm{~cm}$ & binding & Mineral - asphalt mix - ACWMS 16 W (lepiszcze 20/30) \\
\hline $18 \mathrm{~cm}$ & foundation & Mineral - asphalt mix - ACWMS 16 P (lepiszcze 20/30) \\
\hline $22 \mathrm{~cm}$ & $\begin{array}{c}\text { unbound } \\
\text { foundation }\end{array}$ & Crushed-stone aggregate mechanically stabilized $-0 / 31,5 ; \mathrm{E}_{2} \geq 180 \mathrm{MPa}$ \\
\hline $25 \mathrm{~cm}$ & frost-protection $/$ & Unbound mix, CBR $>40 \%, \mathrm{E}_{2} \geq 140 \mathrm{MPa}$ \\
\hline $15-25$ & filtering & Ground stabilized with cement, $\mathrm{R}_{\mathrm{m}}=2,5 \mathrm{MPa}$ \\
\hline $\mathrm{cm}$ & improved substrate & Native ground \\
\hline
\end{tabular}

\section{Summary}

The enormous increase in road traffic, the increase in the total weight of lorries and the load on individual vehicle axles, have resulted in the need for extensive use of pavements, which allow the transfer of increased loads (Szydło A., p. 25). At the same time, the requirements regarding the exploitation characteristics of the surface, the length of service and the fatigue life of the pavement increased.

The length of highways in Lower Silesia with a structure that allows the load to be transferred $115 \mathrm{kN} /$ axle, totals $435.452 \mathrm{~km}$. This accounts for $6.6 \%$ of all national roads -115 $\mathrm{kN} / \mathrm{axle}$ in Poland. It is also $33.26 \%$ of national roads in the area administered by GDDKiA Branch in Wrocław. 


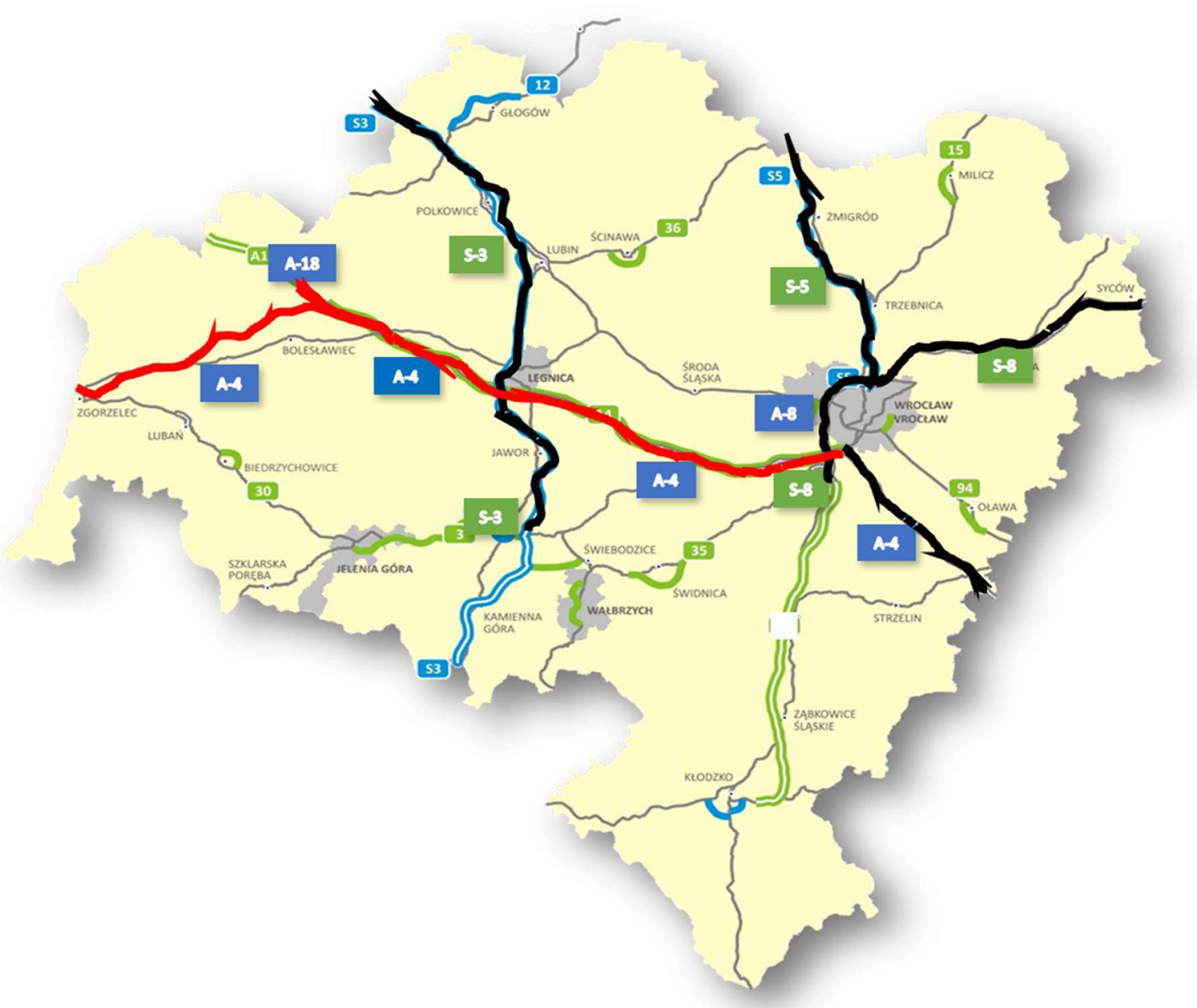

4. Structures of class A and S road surfaces in Lower Silesia. (Source: GDDKiA Wrocław Branch.)

In Lower Silesia, 159,043 km of class A and S roads have a rigid pavement structure, and on the length of $276.409 \mathrm{~km}$ of expressways, the susceptible surface dominates (source: GDDKiA Wrocław Branch). Motorways and express roads with rigid construction (red color) and with a flexible construction (black color) are shown in Figure 4.

Lower Silesia as a border region is an important element of transport routes in Poland and in Europe. It borders with Germany in the west and the Czech Republic in the south.

The network of national roads, including high-speed roads - class A and S roads, despite the large variety of pavement construction, is appropriately prepared for fast, comfortable and safe conduct of heavy transit traffic and local traffic.

\section{Source materials}

[1] GDDKiA Oddział we Wrocławiu. Wydział Technologii - Laboratorium Drogowe. Archiwum podręczne.

[2] Katalog Typowych Konstrukcji Nawierzchni Podatnych i Półsztywnych. Politechnika Gdańska, GDDKiA. Warszawa 2014

[3] Katalog Typowych Konstrukcji Nawierzchni Sztywnych. Politechnika Wrocławska, GDDKiA. Warszawa 2014

[4] Szydło A. „Nawierzchnie drogowe z betonu cementowego. Teoria. Wymiarowanie. Realizacja”. Polski Cement Sp. z o. o. Kraków 2004. 